 \\ z Filologii Polskiej \\ i Słowiańskiej
}

\author{
Radosław Kaleta \\ (Uniwersytet Warszawski)
}

\section{O potrzebie ujednolicenia sposobów transliteracji imion i nazwisk białoruskich w Polsce}

Niniejszy artykuł ma na celu przedstawienie zagadnienia transliteracji alfabetu białoruskiego z synchronicznego punktu widzenia, ale warto na wstępie przytoczyć choć kilka faktów historycznych dotyczących alfabetu białoruskiego. Białoruski alfabet łaciński (tzw. łacinka) ma swoją historię. Na przykład w latach 1862-1863 publikowano łacinką pierwszą rewolucyjną gazetę białoruską „Mużyckaja prauda” Konstantego Kalinowskiego (brus. Кастусь Каліноўскі). Kolportowana była głównie na Białostocczyźnie i Grodzieńszczyźnie. Większość zabytków piśmiennictwa końca XIX w. (około 75 książek po białorusku) była wydana łacinką, czyli wariantem alfabetu łacińskiego dostosowanym do potrzeb białoruszczyzny (z elementami alfabetu husyckiego czy serbsko-chorwackiego [Lubaś, 2009, s. 274; por. Smułkowa, 2002, s. 384]), co zbliżało język białoruski do rodziny języków zachodniosłowiańskich (Плотнікаў, 2000, s. 40). Nawet do początku XX w. łacinka i cyrylica były często używane i współistniały ze sobą, np. gazeta „Nasza Dola” była wydawana cyrylicą dla prawosławnych, a łacinką dla katolików (por. Romanowski, 2000, s. 130). Białoruska łacinka na początku XX w. była stosowana w prasie w polskim, a później czeskim wariancie (Lukašanec, Prigodzič, \& Sjameška, 1998, s. 16). Zachowała

This is an Open Access article distributed under the terms of the Creative Commons Attribution 3.0 PL License (creativecommons.org/licenses/by/3.0/pl/), which permits redistribution, commercial and non-commercial, provided that the article is properly cited. (c) The Author(s) 2017. 
przewagę $\mathrm{w}$ drukach białoruskich w Wilnie oraz na emigracji (por. Romanowski, 2000, s. 130). Również gazeta „Nasza Niwa” od 1906 r. wydawana była łacinką. Pierwsza opublikowana (1918 r.) gramatyka języka białoruskiego autorstwa Bronisława Taraszkiewicza miała także wariant drukowany cyrylicą i łacinką, a sam autor przedstawił w swej książce litery białoruskiego alfabetu łacińskiego, który w latach 60. XX w. został zmodyfikowany i zaprezentowany przez białoruskiego językoznawcę Jana Stankiewicza (brus. Янка Станкевіч). Łacinka była uważana za bardziej odpowiedni alfabet dla języka białoruskiego, czemu dała wyraz większość uczestników Białoruskiej Konferencji Akademickiej, która dyskutowała nad pisownią w Mińsku w 1926 r. i popierała pomysł przejścia z cyrylicy na łacinkę, co parę lat później było uznane przez bolszewików za sztuczną próbę oderwania języka białoruskiego od rosyjskiego (Баршчэўская, 2004, s. 18). W zachodniej Białorusi, która po traktacie ryskim (1921 r.) znalazła się w obrębie II RP, łacinka była wykorzystywana w środowisku białoruskich katolików, choć ogólnie wykorzystywano cyrylicę, co miało bronić przed polonizacją i nawiązywać do tendencji Białoruskiej Socjalistycznej Republiki Radzieckiej. Obecnie na podstawie tradycyjnej łacinki powstała białoruska transliteracja białoruskich nazw geograficznych, o czym w dalszej części artykułu.

W sytuacji narastającej światowej migracji ludności nie dziwi fakt, że w Polsce coraz bardziej widoczna jest obecność obywateli krajów WNP, z Ukraińcami, Białorusinami i Rosjanami na czele. Wszyscy oni stykają się w Polsce (a także w innych państwach) z problemem pisowni własnych imion i nazwisk. W przypadku Białorusinów kwestię tą komplikuje tzw. „dwujęzyczność państwowa” (por. Lukašanec, Prigodzič, \& Sjameška, 1998, ss. 19, 31-36; Лукашанец, 2014, s. 24; zob. też Łodziński, 2005) funkcjonująca na Białorusi, która powoduje, że Białorusini mają nazwiska $w$ formie rosyjskiej i białoruskiej, a co się z tym wiąże, transliterowane są z form albo rosyjskich, albo białoruskich, które różnią się od siebie, choć dotyczą tej samej osoby.

W paszportach stosowana jest transliteracja Organizacji Międzynarodowego Lotnictwa Cywilnego (International Civil Aviation Organization, ICAO) z uwzględnieniem 26 liter alfabetu angielskiego. Wcześniej w białoruskich paszportach opierano się na systemie transkrypcji francuskiej, która ma swoje osobliwości (np. brus. Лукашэнка - fr. Loukachenka, brus. $y=$ fr. ou, brus. $u=$ fr. $c h$ ), potem białoruskie MSW stosowało wypracowane zasady na bazie języka angielskiego (więcej: Саўка, 2011; Кошчанка, 2015). Standard opracowany przez Organizację Międzynarodowego Lotnictwa Cywilnego dostosowany jest do specjalnych czytników elektronicznych. Narodowy wariant nazwiska 
zapisany w paszporcie ma swój specjalny odpowiednik na dole strony, którą przykłada się do maszyny-czytnika na lotnisku, by sprawdzić dane osobowe. Na przykład imię RADOSŁAW w polskim paszporcie ma na dole odpowiednik RADOSLAW (pisane wielkimi literami; L zamiast $Ł$ ). System ten ma ułatwić maszynie wczytanie danych, nie uwzględnia zatem narodowych cech charakterystycznych dla danego języka (np. pol. Ł). Problemu nie ma, jeśli imię i nazwisko nie zawierają liter charakterystycznych dla danego języka, np. KNYSH (od brus. KHbıw), w takim przypadku formy nazwisk i imion na dole i górze strony paszportowej są takie same. Urzędy białoruskie powołują się na ten system jako międzynarodowy (przyjęty też w paszportach rosyjskich, służących za wzór dla białoruskich), ale nie uwzględniają jego technicznej specyfiki nieoddającej osobliwości językowych danego narodu (zob. Кошчанка, 2015, s. 174), nie jest on bowiem transkrypcją dostosowaną do białoruskiej wymowy. Przykłady transliteracji OMLC (ICAO) podano w tabeli (używane są tylko wielkie litery). Cechy szczególne zostały zaznaczone czcionką pogrubioną.

Tabela 1. Transliteracja alfabetu białoruskiego Organizacji Międzynarodowego Lotnictwa Cywilnego

\begin{tabular}{|c|c|}
\hline $\begin{array}{c}\text { Alfabet } \\
\text { białoruski }\end{array}$ & $\begin{array}{l}\text { Transliteracja Organiza- } \\
\text { cji Międzynarodowego } \\
\text { Lotnictwa Cywilnego }\end{array}$ \\
\hline $\mathrm{A}, \mathrm{a}$ & A \\
\hline Б, 6 & B \\
\hline $\mathrm{B}, \mathrm{B}$ & $\mathrm{V}$ \\
\hline$\Gamma, \Gamma$ & $\mathbf{H}$ \\
\hline Д, д & $\mathrm{D}$ \\
\hline $\mathrm{E}, \mathrm{e}$ & $\mathrm{E}$ \\
\hline Ë, ë & IO \\
\hline Ж, ж & $\mathbf{Z H}$ \\
\hline 3,3 & $\mathrm{Z}$ \\
\hline $\mathrm{I}, \mathrm{i}$ & I \\
\hline$\breve{И}$, й & I \\
\hline К, К & $\mathrm{K}$ \\
\hline Л, л & $\mathbf{L}$ \\
\hline $\mathrm{M}, \mathrm{M}$ & $\mathrm{M}$ \\
\hline $\mathrm{H}, \mathrm{H}$ & $\mathrm{N}$ \\
\hline $\mathrm{O}, \mathrm{o}$ & $\mathrm{O}$ \\
\hline
\end{tabular}

\begin{tabular}{|c|c|}
\hline $\begin{array}{c}\text { Alfabet } \\
\text { białoruski }\end{array}$ & $\begin{array}{l}\text { Transliteracja Organiza- } \\
\text { cji Międzynarodowego } \\
\text { Lotnictwa Cywilnego }\end{array}$ \\
\hline$\Pi, \Pi$ & $\mathrm{P}$ \\
\hline $\mathrm{P}, \mathrm{p}$ & $\mathrm{R}$ \\
\hline $\mathrm{C}, \mathrm{c}$ & $S$ \\
\hline $\mathrm{T}, \mathrm{T}$ & $\mathrm{T}$ \\
\hline $\mathrm{y}, \mathrm{y}$ & $\mathrm{U}$ \\
\hline y̆, y̆ & $\mathbf{U}$ \\
\hline$\Phi, \phi$ & $\mathrm{F}$ \\
\hline $\mathrm{X}, \mathrm{x}$ & KH \\
\hline Ц, ц & TS \\
\hline ૫, ч & $\mathrm{CH}$ \\
\hline Ш, ш & SH \\
\hline Ы, ы & $\mathrm{Y}$ \\
\hline Э, э & $\mathrm{E}$ \\
\hline Ю, ю & IU \\
\hline Я, я & IA \\
\hline
\end{tabular}


Inny sposób transliteracji cyrylicy (w tym imion i nazwisk autorów) proponuje międzynarodowy standard ISO 9 z 1995 r., w Polsce funkcjonujący jako PN-ISO 9:2000 (Informacja i dokumentacja. Transliteracja znaków cyrylickich na znaki łacińskie - Języki słowiańskie i niesłowiańskie; International Organization for Standardization, 2000) i służący do opisów bibliograficznych (różnice zaznaczono w poniższej tabeli drukiem pogrubionym). ISO to nazwa oznaczająca Międzynarodową Organizację Normalizacyjną (The International Organization for Standardization).

Tabela 2. Transliteracja alfabetu białoruskiego wg normy ISO 9 z 1995 r.

\begin{tabular}{|c|c|}
\hline $\begin{array}{l}\text { Alfabet biało- } \\
\text { ruski }\end{array}$ & $\begin{array}{c}\text { Transliteracja ISO 9: } \\
\text { 1995 } \\
\text { PN-ISO 9:2000 }\end{array}$ \\
\hline $\mathrm{A}, \mathrm{a}$ & $\mathrm{A}, \mathrm{a}$ \\
\hline Б, 6 & $\mathrm{~B}, \mathrm{~b}$ \\
\hline B, в & $\mathrm{V}, \mathrm{v}$ \\
\hline$\Gamma, \Gamma$ & G, g \\
\hline Д, д & $\mathrm{D}, \mathrm{d}$ \\
\hline E, e & E, e \\
\hline$\ddot{\mathrm{E}}, \mathrm{e}$ & $\ddot{\mathrm{E}}, \mathrm{e}$ \\
\hline Ж, ж & $\check{\mathbf{Z}}, \check{\mathbf{z}}$ \\
\hline 3,3 & $\mathrm{Z}, \mathrm{z}$ \\
\hline $\mathrm{I}, \mathrm{i}$ & $\overline{\mathbf{I}}, \mathbf{i}$ \\
\hline Й, й & $\mathbf{J}, \mathbf{j}$ \\
\hline K, К & $\mathrm{K}, \mathrm{k}$ \\
\hline Л, л & $\mathrm{L}, \mathrm{l}$ \\
\hline $\mathrm{M}, \mathrm{M}$ & $\mathrm{M}, \mathrm{m}$ \\
\hline $\mathrm{H}, \mathrm{H}$ & $\mathrm{N}, \mathrm{n}$ \\
\hline $\mathrm{O}, \mathrm{o}$ & $\mathrm{O}, \mathrm{o}$ \\
\hline$\Pi, \Pi$ & $\mathrm{P}, \mathrm{p}$ \\
\hline
\end{tabular}

\begin{tabular}{|c|c|}
\hline $\begin{array}{l}\text { Alfabet biało- } \\
\text { ruski }\end{array}$ & $\begin{array}{c}\text { Transliteracja ISO 9: } \\
1995 \\
\text { PN-ISO 9:2000 }\end{array}$ \\
\hline $\mathrm{P}, \mathrm{p}$ & $\mathrm{R}, \mathrm{r}$ \\
\hline $\mathrm{C}, \mathrm{c}$ & S, s \\
\hline $\mathrm{T}, \mathrm{T}$ & $\mathrm{T}, \mathrm{t}$ \\
\hline $\mathrm{y}, \mathrm{y}$ & $\mathrm{U}, \mathrm{u}$ \\
\hline$\check{\mathrm{y}}, \mathrm{y}$ & $\breve{\mathbf{U}}, \breve{\mathbf{u}}$ \\
\hline$\Phi, \phi$ & $\mathrm{F}, \mathrm{f}$ \\
\hline $\mathrm{X}, \mathrm{x}$ & H, h \\
\hline Ц, ц & C, c \\
\hline Ч, ч & $\check{C}, \check{c}$ \\
\hline Ш, ш & $\check{\mathbf{S}}, \check{s}$ \\
\hline , & , \\
\hline Ы, ы & $\mathrm{Y}, \mathrm{y}$ \\
\hline $\mathrm{b}$ & , \\
\hline Э, э & $\grave{\mathbf{E}}, \grave{\mathbf{e}}$ \\
\hline Ю, ю & $\hat{\mathbf{U}}, \hat{\mathbf{u}}$ \\
\hline Я, я & $\hat{\mathbf{A}}, \hat{\mathbf{a}}$ \\
\hline
\end{tabular}

W 2007 r. władze białoruskie zgłosiły do ONZ oficjalną transliterację białoruskich nazw geograficznych (por. Саўка, 2011, ss. 234-235). Projekt został zalecony do użytku przez Grupę Ekspertów ONZ ds. Nazw Geograficznych $\mathrm{w} 2012 \mathrm{r}$. (por. Report on the current status of United Nations romanization systems for geographical names, b.d.). W kontekście niniejszego artykułu jest to ważne, ponieważ pojawiają się na Białorusi głosy, by stosować tę transliterację oficjalnie w każdym przypadku, nie tylko w nazwach geograficznych, lecz także w paszpor- 
tach, podręcznikach dla obcokrajowców itd. (por. Кошчанка, 2015, s. 178), żeby uniknąć paradoksu stosowania różnych transliteracji w jednym tekście - jednej do nazwisk, drugiej do nazw geograficznych (por. Кошчанка, 2015, s. 177).

Tabela 3. Oficjalna transliteracja białoruskich nazw geograficznych zalecona przez ONZ

\begin{tabular}{|c|c|c|}
\hline $\begin{array}{l}\text { Alfabet } \\
\text { białoruski }\end{array}$ & $\begin{array}{c}\text { Transliteracja } \\
\text { (oficjalny system białoruski z } 2007 \text { r. } \\
\text { zalecony przez ONZ w } 2012 \text { r.) }\end{array}$ & $\begin{array}{l}\text { Przykłady (Инструкиия по } \\
\text { транслитерации...) }\end{array}$ \\
\hline A, a & A, a & Аршанскі - Aršanski \\
\hline Б, 6 & $\mathrm{~B}, \mathrm{~b}$ & Бешанковічы - Biešankovičy \\
\hline $\mathrm{B}, \mathrm{B}$ & $\mathrm{V}, \mathrm{v}$ & Віцебск - Viciebsk \\
\hline$\Gamma, \Gamma$ & $\mathrm{H}, \mathrm{h}$ & Гомель - Нomieĺ, Гаўя - Наŭja \\
\hline Д, д & $\mathrm{D}, \mathrm{d}$ & Добруш - Dobruš \\
\hline \multirow[t]{2}{*}{ E, e } & $\begin{array}{l}\text { Je - na początku wyrazu, po samogło- } \\
\text { sce, po apostrofie ('), znaku miękkim } \\
\text { (b) po } u \text { niezgłoskotwórczym (y) }\end{array}$ & Ельск - Jel̂sk, Бабаедава - Babajedava \\
\hline & ie - po spółgłosce (też Л, л) & Венцавічы - Viencavičy \\
\hline \multirow[t]{2}{*}{ Ë, ë } & $\begin{array}{l}\text { Jo - na początku wyrazu, po samogło- } \\
\text { sce, po apostrofie ('), znaku miękkim } \\
\text { (b) po } u \text { niezgłoskotwórczym (y̆) }\end{array}$ & Ёды - Jody, Вераб’ёвічы - Vierabjovičy \\
\hline & io - po spółgłosce (też Л, л) & Mёры - Miory \\
\hline Ж, ж & $\check{Z}, \check{z}$ & Жодзішкі - Žodziški \\
\hline 3,3 & $\mathrm{Z}, \mathrm{z}$ & Зэльва - Zeĺva \\
\hline $\mathrm{I}, \mathrm{i}$ & $\mathrm{I}, \mathrm{i}$ & Іванава - Ivanava, Iy̆e - Iŭje \\
\hline$\breve{И}$, й & $\mathrm{J}, \mathrm{j}$ & Лагойск - Lahojsk \\
\hline K, K & $\mathrm{K}, \mathrm{k}$ & Круглае - Kruhlaje \\
\hline \multirow[t]{2}{*}{ Л, л } & $\mathrm{L}, \mathrm{l}$ & Лошыца - Lošyca, Любань - Liubań \\
\hline & $\begin{array}{l}\text { L, I - gdy po literze występuje znak } \\
\text { miękki (b) }\end{array}$ & Фаніпаль - Fanipal \\
\hline $\mathrm{M}, \mathrm{M}$ & $\mathrm{M}, \mathrm{m}$ & Магілёў - Mahilioŭ \\
\hline \multirow[t]{2}{*}{$\mathrm{H}, \mathrm{H}$} & $\mathrm{N}, \mathrm{n}$ & Нясвіж - Niasviž \\
\hline & $\begin{array}{l}\text { Ń, ń - gdy po literze występuje znak } \\
\text { miękki (b) }\end{array}$ & Любань - Liubań \\
\hline $\mathrm{O}, \mathrm{o}$ & $\mathrm{O}, \mathrm{o}$ & Орша - Orša \\
\hline$\Pi, \Pi$ & $\mathrm{P}, \mathrm{p}$ & Паставы - Pastavy \\
\hline $\mathrm{P}, \mathrm{p}$ & $\mathrm{R}, \mathrm{r}$ & Рагачоў - Rahačoŭ \\
\hline \multirow[t]{2}{*}{$\mathrm{C}, \mathrm{c}$} & $\mathrm{S}, \mathrm{s}$ & Светлагорск - Svietlahorsk \\
\hline & $\begin{array}{l}\text { Ś, ś - gdy po literze występuje znak } \\
\text { miękki (b) }\end{array}$ & Беларусь - Bielaruś \\
\hline
\end{tabular}




\begin{tabular}{|c|c|c|}
\hline $\begin{array}{l}\text { Alfabet } \\
\text { białoruski }\end{array}$ & $\begin{array}{c}\text { Transliteracja } \\
\text { (oficjalny system białoruski z } 2007 \text { r. } \\
\text { zalecony przez ONZ w } 2012 \text { r.) }\end{array}$ & $\begin{array}{l}\text { Przykłady (Инструкция по } \\
\text { транслитерации...) }\end{array}$ \\
\hline $\mathrm{T}, \mathrm{T}$ & $\mathrm{T}, \mathrm{t}$ & Талачын - Talačyn \\
\hline $\mathrm{y}, \mathrm{y}$ & $\mathrm{U}, \mathrm{u}$ & Узда - Uzda \\
\hline$\breve{y}, \breve{y}$ & $\breve{\mathrm{U}}, \breve{\mathrm{u}}$ & Шаркаўшчына - Šarkaǔščyna \\
\hline$\Phi, \phi$ & $F, f$ & Фаніпаль - Fanipaĺ \\
\hline $\mathrm{X}, \mathrm{x}$ & $\mathrm{Ch}, \mathrm{ch}$ & Хоцімск - Chocimsk \\
\hline \multirow[t]{2}{*}{ Ц, ц } & $\mathrm{C}, \mathrm{c}$ & Цёмны Лес - Ciomny Lies \\
\hline & $\begin{array}{l}\text { Ć, ć - gdy po literze występuje znak } \\
\text { miękki (b) }\end{array}$ & Друць -Druć \\
\hline Ч, ૫ & $\check{C}, \check{c}$ & Чавусы - Čavusy \\
\hline Ш, ш & $\check{S}$ S, š & Шуміліна - Šumilina \\
\hline , & Pomija się & \\
\hline Ы, ы & $\mathrm{Y}, \mathrm{y}$ & Чыгірынка - Čyhirynka \\
\hline$Э, \ni$ & $\mathrm{E}, \mathrm{e}$ & Чачэрск - Čačersk \\
\hline \multirow[t]{2}{*}{ Ю, ю } & $\begin{array}{l}\text { Ju, ju - na początku wyrazu, po samo- } \\
\text { głosce, po apostrofie ('), znaku miękkim } \\
\text { (b) po } u \text { niezgłoskotwórczym (y̆) }\end{array}$ & $\begin{array}{l}\text { Юхнаўка - Juchnaŭka, Гаюціна - } \\
\text { Hajucina }\end{array}$ \\
\hline & iu - po spółgłosce (też Л, л) & Цюрлі - Ciurli, Любонічы - Liuboničy \\
\hline \multirow[t]{2}{*}{ Я, я } & $\begin{array}{l}\text { Ja, ja - na początku wyrazu, po samo- } \\
\text { głosce, po apostrofie ('), znaku mięk- } \\
\text { kim (b) po } u \text { niezgłoskotwórczym (y̆) }\end{array}$ & Ямнае - Jamnaje, Баяры - Bajary \\
\hline & ia - po spółgłosce (też Л, л) & $\begin{array}{l}\text { Валяр'яны - Valiarjany, Вязынка - } \\
\text { Viazynka }\end{array}$ \\
\hline
\end{tabular}

W Polsce stosowana jest transkrypcja (a nie transliteracja) polska, dostępna m.in. w Wielkim słowniku ortograficznym PWN (Polański, 2013; zob. też Bańko, 2006, ss. 469-471). Została ona także prawnie ogłoszona w Rozporzadzeniu Ministra Spraw Wewnętrznych i Administracji z dnia 30 maja 2005 r. $w$ sprawie sposobu transliteracji imion i nazwisk osób należacych do mniejszości narodowych i etnicznych zapisanych $w$ alfabecie innym niż alfabet łaciński (Dz. U. Nr 102, poz. 855) (2005). Nazwa dokumentu jest myląca, gdyż w zasadzie nie chodzi o transliterację, lecz transkrypcję z uwzględnieniem zasad polskiej ortografii, o czym świadczy wprost używany w dokumencie czasownik transkrybujemy (to zresztą nie jedyny błąd w tekście). 
Tabela 4. Transkrypcja polska alfabetu białoruskiego

\begin{tabular}{|c|c|c|c|}
\hline $\begin{array}{c}\text { Alfabet } \\
\text { białoruski }\end{array}$ & Transkrypcja polska & $\begin{array}{c}\text { Alfabet } \\
\text { białoruski }\end{array}$ & Transkrypcja polska \\
\hline $\mathrm{A}, \mathrm{a}$ & $\mathrm{A}, \mathrm{a}$ & $\mathrm{T}, \mathrm{T}$ & $\mathrm{T}, \mathrm{t}$ \\
\hline Б, 6 & $\mathrm{~B}, \mathrm{~b}$ & $\mathrm{y}, \mathrm{y}$ & $\mathrm{U}, \mathrm{u}$ \\
\hline $\mathrm{B}, \mathrm{B}$ & $\mathrm{W}, \mathrm{w}$ & y̆, y̆ & $\mathrm{U}, \mathrm{u}$ \\
\hline$\Gamma, \Gamma$ & $\mathrm{H}, \mathrm{h}$ & $\Phi, \phi$ & $F, f$ \\
\hline Д, д & $\mathrm{D}, \mathrm{d}$ & $\mathrm{X}, \mathrm{x}$ & Ch, ch \\
\hline \multirow{4}{*}{ E, e } & \multirow{4}{*}{$\begin{array}{l}\text { Je, je - na początku wyrazu, } \\
\text { po samogłosce, po apostrofie } \\
\text { ('), znaku miękkim (b) } \\
\text { e - po Л, л } \\
\text { ie - po innych spółgłoskach }\end{array}$} & Ц, ц & $\mathrm{C}, \mathrm{c}$ \\
\hline & & Ч, ч & $\mathrm{Cz}, \mathrm{cz}$ \\
\hline & & Ш, ш & $\mathrm{Sz}, \mathrm{sz}$ \\
\hline & & , & Pomija się \\
\hline \multirow[b]{2}{*}{$\ddot{\mathrm{E}}, \ddot{\mathrm{e}}$} & \multirow{2}{*}{$\begin{array}{l}\text { Jo, jo - na początku wyrazu, } \\
\text { po samogłosce, po apostrofie } \\
\text { ('), znaku miękkim (b) } \\
\text { o - po Л, л } \\
\text { io - po innych spółgłoskach }\end{array}$} & Ы, ы & $\mathrm{Y}, \mathrm{y}$ \\
\hline & & $\mathrm{b}$ & $\begin{array}{l}\text { Znak miękkości zaznaczany } \\
\text { jest nad literami: Ć, ć, Ń, ń, S, } \\
\text { ś, Ź, ź. Pomijany jest po Л, л. } \\
\text { Ль, Ль zapisywane jest jako L, l }\end{array}$ \\
\hline Ж, ж & $\dot{\mathrm{Z}}, \dot{\mathrm{z}}$ & Э, э & $\mathrm{E}, \mathrm{e}$ \\
\hline 3,3 & $\mathrm{Z}, \mathrm{z}$ & \multirow{4}{*}{ Ю, ю } & \multirow{4}{*}{$\begin{array}{l}\text { Ju, ju - na początku wyrazu, } \\
\text { po samogłosce, po apostrofie } \\
\text { ('), znaku miękkim (b) } \\
\text { u - po Л, л } \\
\text { iu - po innych spółgłoskach }\end{array}$} \\
\hline $\mathrm{I}, \mathrm{i}$ & $\mathrm{I}, \mathrm{i}$ & & \\
\hline$\breve{И}$, Й & $\mathrm{J}, \mathrm{j}$ & & \\
\hline K, K & $\mathrm{K}, \mathrm{k}$ & & \\
\hline Л, л & $\begin{array}{l}\mathrm{L}, 1-\text { przed e, ë, Я, ю, i, ь } \\
Ł, ł \text { - przed spółgłoskami, } \\
\text { przed samogłoskami a, o, y, } \\
\text { oraz na końcu wyrazu }\end{array}$ & \multirow[t]{2}{*}{ Я, я } & \multirow{2}{*}{$\begin{array}{l}\text { Ja, ja - na początku wyrazu, } \\
\text { po samogłosce, po apostrofie } \\
\text { ('), znaku miękkim (b) } \\
\text { a - po Л, л } \\
\text { ia - po innych spółgłoskach }\end{array}$} \\
\hline $\mathrm{M}, \mathrm{M}$ & $\mathrm{M}, \mathrm{m}$ & & \\
\hline $\mathrm{H}, \mathrm{H}$ & $\mathrm{N}, \mathrm{n}$ & & \\
\hline $\mathrm{O}, \mathrm{o}$ & $\mathrm{O}, \mathrm{o}$ & & \\
\hline$\Pi, \Pi$ & $\mathrm{P}, \mathrm{p}$ & & \\
\hline $\mathrm{P}, \mathrm{p}$ & $\mathrm{R}, \mathrm{r}$ & & \\
\hline $\mathrm{C}, \mathrm{c}$ & $S, s$ & & \\
\hline
\end{tabular}


Niżej zaprezentowano porównanie najaktualniejszych standardów dotyczących transliteracji alfabetu języka białoruskiego.

Tabela 5. Porównanie najpopularniejszych wariantów transliteracji alfabetu języka białoruskiego

\begin{tabular}{|c|c|c|c|c|}
\hline $\begin{array}{l}\text { Alfabet } \\
\text { biało- } \\
\text { ruski }\end{array}$ & $\begin{array}{l}\text { Transliteracja } \\
\text { Organizacji } \\
\text { Międzynaro- } \\
\text { dowego Lotnic- } \\
\text { twa Cywilnego } \\
\text { (stosowana } \\
\text { w paszportach) }\end{array}$ & $\begin{array}{l}\text { Transliteracja } \\
\text { ISO 9: } 1995 \\
\text { PN-ISO } \\
\text { 9:2000 } \\
\text { (dotyczy zapi- } \\
\text { sów bibliogra- } \\
\text { ficznych) }\end{array}$ & $\begin{array}{c}\text { Transliteracja } \\
\text { (oficjalny system } \\
\text { białoruski z } 2007 \text { r. } \\
\text { zalecony przez ONZ } \\
\text { w } 2012 \text { r., dotyczy } \\
\text { zapisów nazw geogra- } \\
\text { ficznych) }\end{array}$ & Transkrypcja polska \\
\hline A, a & A & A, a & A, a & A, a \\
\hline 5,6 & B & $\mathrm{B}, \mathrm{b}$ & $\mathrm{B}, \mathrm{b}$ & $\mathrm{B}, \mathrm{b}$ \\
\hline $\mathrm{B}, \mathrm{B}$ & $\mathrm{V}$ & $\mathrm{V}, \mathrm{v}$ & $\mathrm{V}, \mathrm{v}$ & $\mathrm{W}, \mathrm{w}$ \\
\hline$\Gamma, \Gamma$ & $\mathrm{H}$ & $\mathrm{G}, \mathrm{g}$ & $\mathrm{H}, \mathrm{h}$ & $\mathrm{H}, \mathrm{h}$ \\
\hline Д, д & $\mathrm{D}$ & $\mathrm{D}, \mathrm{d}$ & $\mathrm{D}, \mathrm{d}$ & $\mathrm{D}, \mathrm{d}$ \\
\hline $\mathrm{E}, \mathrm{e}$ & $\mathrm{E}$ & $\mathrm{E}, \mathrm{e}$ & $\begin{array}{l}\text { Je - na początku wy- } \\
\text { razu, po samogłosce, } \\
\text { po apostrofie ('), znaku } \\
\text { miękkim (b) po } u \text { nie- } \\
\text { zgłoskotwórczym (y̆) } \\
\text { ie - po spółgłosce }\end{array}$ & $\begin{array}{l}\text { Je, je - na początku wyrazu, } \\
\text { po samogłosce, po apostrofie } \\
\text { ('), znaku miękkim (b) } \\
\text { e - po Л, л } \\
\text { ie - po innych spółgłoskach }\end{array}$ \\
\hline$\ddot{\mathrm{E}}, \ddot{\mathrm{e}}$ & IO & $\ddot{\mathrm{E}}, \ddot{\mathrm{e}}$ & $\begin{array}{l}\text { Jo - na początku wy- } \\
\text { razu, po samogłosce, } \\
\text { po apostrofie ('), znaku } \\
\text { miękkim (b) po } u \text { nie- } \\
\text { zgłoskotwórczym (y̆) } \\
\text { io - po spółgłosce }\end{array}$ & $\begin{array}{l}\text { Jo, jo - na początku wyrazu, } \\
\text { po samogłosce, po apostrofie } \\
\text { ('), znaku miękkim (b) } \\
\text { o - po Л, л } \\
\text { io - po innych spółgłoskach }\end{array}$ \\
\hline Ж, ж & $\mathrm{ZH}$ & $\check{Z}, \check{z}$ & $\check{Z}, \check{Z}$ & $\dot{\mathrm{Z}}, \dot{\mathrm{z}}$ \\
\hline 3,3 & $\mathrm{Z}$ & $\mathrm{Z}, \mathrm{z}$ & $\mathrm{Z}, \mathrm{z}$ & $\mathrm{Z}, \mathrm{z}$ \\
\hline $\mathrm{I}, \mathrm{i}$ & I & $\grave{I}, \grave{i}$ & $\mathrm{I}, \mathrm{i}$ & $\mathrm{I}, \mathrm{i}$ \\
\hline$\breve{И}$, Й & I & $J, j$ & $\mathrm{~J}, \mathrm{j}$ & $J, j$ \\
\hline$K, \mathrm{~K}$ & K & $\mathrm{K}, \mathrm{k}$ & $\mathrm{K}, \mathrm{k}$ & $\mathrm{K}, \mathrm{k}$ \\
\hline Л, л & $\mathrm{L}$ & $\mathrm{L}, 1$ & $\mathrm{~L}, 1$ & $\begin{array}{l}\text { L, l- przed e, ë, я, ю, i, ь } \\
\text { Ł, } 1 \text { - przed spółgłoskami, } \\
\text { przed samogłoskami a, o, } \\
\text { y, b oraz na końcu wyrazu }\end{array}$ \\
\hline $\mathrm{M}, \mathrm{M}$ & $\mathrm{M}$ & $\mathrm{M}, \mathrm{m}$ & $\mathrm{M}, \mathrm{m}$ & $\mathrm{M}, \mathrm{m}$ \\
\hline $\mathrm{H}, \mathrm{H}$ & $\mathrm{N}$ & $\mathrm{N}, \mathrm{n}$ & $\mathrm{N}, \mathrm{n}$ & $\mathrm{N}, \mathrm{n}$ \\
\hline $\mathrm{O}, \mathrm{o}$ & $\mathrm{O}$ & $\mathrm{O}, \mathrm{o}$ & $\mathrm{O}, \mathrm{o}$ & $\mathrm{O}, \mathrm{o}$ \\
\hline
\end{tabular}




\begin{tabular}{|c|c|c|c|c|}
\hline $\begin{array}{l}\text { Alfabet } \\
\text { biało- } \\
\text { ruski }\end{array}$ & $\begin{array}{l}\text { Transliteracja } \\
\text { Organizacji } \\
\text { Międzynaro- } \\
\text { dowego Lotnic- } \\
\text { twa Cywilnego } \\
\text { (stosowana } \\
\text { w paszportach) }\end{array}$ & $\begin{array}{l}\text { Transliteracja } \\
\text { ISO 9: } 1995 \\
\text { PN-ISO } \\
\text { 9:2000 } \\
\text { (dotyczy zapi- } \\
\text { sów bibliogra- } \\
\text { ficznych) }\end{array}$ & $\begin{array}{c}\text { Transliteracja } \\
\text { (oficjalny system } \\
\text { białoruski z } 2007 \text { r. } \\
\text { zalecony przez ONZ } \\
\text { w } 2012 \text { r., dotyczy } \\
\text { zapisów nazw geogra- } \\
\text { ficznych) }\end{array}$ & Transkrypcja polska \\
\hline$\Pi, \Pi$ & $\mathrm{P}$ & $\mathrm{P}, \mathrm{p}$ & $\mathrm{P}, \mathrm{p}$ & $\mathrm{P}, \mathrm{p}$ \\
\hline $\mathrm{P}, \mathrm{p}$ & $\mathrm{R}$ & $\mathrm{R}, \mathrm{r}$ & $\mathrm{R}, \mathrm{r}$ & $\mathrm{R}, \mathrm{r}$ \\
\hline $\mathrm{C}, \mathrm{c}$ & $S$ & S, s & $\mathrm{S}, \mathrm{s}$ & $S, s$ \\
\hline $\mathrm{T}, \mathrm{T}$ & $\mathrm{T}$ & $\mathrm{T}, \mathrm{t}$ & $\mathrm{T}, \mathrm{t}$ & $\mathrm{T}, \mathrm{t}$ \\
\hline $\mathrm{y}, \mathrm{y}$ & $\mathrm{U}$ & $\mathrm{U}, \mathrm{u}$ & $\mathrm{U}, \mathrm{u}$ & $\mathrm{U}, \mathrm{u}$ \\
\hline$\breve{y}, \grave{y}$ & $\mathrm{U}$ & $\breve{\mathrm{U}, \mathrm{u}}$ & $\breve{\mathrm{U}, \mathrm{u}}$ & $\mathrm{U}, \mathrm{u}$ \\
\hline$\Phi, \phi$ & $\mathrm{F}$ & $\mathrm{F}, \mathrm{f}$ & $\mathrm{F}, \mathrm{f}$ & $\mathrm{F}, \mathrm{f}$ \\
\hline $\mathrm{X}, \mathrm{x}$ & $\mathrm{KH}$ & $\mathrm{H}, \mathrm{h}$ & Ch, ch & $\mathrm{Ch}, \mathrm{ch}$ \\
\hline Ц, ц & TS & $\mathrm{C}, \mathrm{c}$ & $\mathrm{C}, \mathrm{c}$ & $\mathrm{C}, \mathrm{c}$ \\
\hline Ч, ч & $\mathrm{CH}$ & $\check{C}, \check{c}$ & $\check{C}, \check{c}$ & $\mathrm{Cz}, \mathrm{cz}$ \\
\hline Ш, ш & $\mathrm{SH}$ & $\check{S}, \check{s}$ & $\check{S}, \check{s}$ & $\mathrm{Sz}, \mathrm{sz}$ \\
\hline , & Pomija się & ' & Pomija się & Pomija się \\
\hline Ы, ы & $\mathrm{Y}$ & $\mathrm{Y}, \mathrm{y}$ & $\mathrm{Y}, \mathrm{y}$ & \begin{tabular}{|c|}
$\mathrm{Y}, \mathrm{y}$ \\
\end{tabular} \\
\hline b & Pomija się & , & $\begin{array}{l}\text { Znak miękkości zazna- } \\
\text { czany jest nad literami: } \\
\text { Ć, ć, N, ń, Ś, ś, Ź, ź oraz } \\
\text { Ĺ, l }\end{array}$ & $\begin{array}{l}\text { Znak miękkości zaznaczany } \\
\text { jest nad literami: Ć, ć, Ń, ń, } \\
\text { Ś, ś, Ź, ź. Pomijany jest po } \\
\text { Л, л. Ль, ль zapisywane jest } \\
\text { jako L, l }\end{array}$ \\
\hline$Э, \ni$ & $\mathrm{E}$ & È, è & E, e & E, e \\
\hline Ю, ю & IU & $\hat{\mathrm{U}}, \mathrm{u}$ & $\begin{array}{l}\text { Ju, ju - na początku } \\
\text { wyrazu, po samogło- } \\
\text { sce, po apostrofie ('), } \\
\text { znaku miękkim (b) } \\
\text { po } u \text { niezgłoskotwór- } \\
\text { czym (y̆) } \\
\text { iu - po spółgłosce }\end{array}$ & $\begin{array}{l}\text { Ju, ju - na początku } \\
\text { wyrazu, po samogłosce, } \\
\text { po apostrofie ('), znaku } \\
\text { miękkim (b) } \\
\text { u - po Л, Л } \\
\text { iu - po innych spółgło- } \\
\text { skach }\end{array}$ \\
\hline Я, я & IA & $\hat{A}, \hat{a}$ & $\begin{array}{l}\text { Ja, ja - na początku } \\
\text { wyrazu, po samogło- } \\
\text { sce, po apostrofie ('), } \\
\text { znaku miękkim (b) } \\
\text { po } u \text { niezgłoskotwór- } \\
\text { czym (y̆) } \\
\text { ia - po spółgłosce }\end{array}$ & $\begin{array}{l}\text { Ja, ja - na początku } \\
\text { wyrazu, po samogłosce, } \\
\text { po apostrofie ('), znaku } \\
\text { miękkim (b) } \\
\text { a - po Л, л } \\
\text { ia - po innych spółgło- } \\
\text { skach }\end{array}$ \\
\hline
\end{tabular}


Wariantów może być znacznie więcej, gdyż poszczególne instytucje na świecie mogą stosować własne odpowiedniki. W poniższej tabeli zaprezentowano litery, które są na różny sposób transliterowane w poszczególnych systemach transliteracji alfabetu języka białoruskiego omówionych we wcześniejszych partiach artykułu.

Tabela 6. Różnice w sposobie transliteracji poszczególnych liter białoruskich

\begin{tabular}{|c|c|c|c|c|}
\hline $\begin{array}{c}\text { Alfabet } \\
\text { białoruski }\end{array}$ & $\begin{array}{l}\text { Transliteracja } \\
\text { Organizacji } \\
\text { Międzynarodo- } \\
\text { wego Lotnictwa } \\
\text { Cywilnego } \\
\text { (stosowana } \\
\text { w paszportach) }\end{array}$ & $\begin{array}{l}\text { Transliteracja } \\
\text { ISO 9: } 1995 \\
\text { PN-ISO 9:2000 } \\
\text { (dotyczy zapi- } \\
\text { sów bibliogra- } \\
\text { ficznych) }\end{array}$ & $\begin{array}{l}\text { Transliteracja } \\
\text { (oficjalny system biało- } \\
\text { ruski z } 2007 \text { r. zalecony } \\
\text { przez ONZ w } 2012 \text { r., } \\
\text { dotyczy zapisów nazw } \\
\text { geograficznych) }\end{array}$ & Transkrypcja polska \\
\hline $\mathrm{B}, \mathrm{B}$ & $\mathrm{V}$ & $\mathrm{V}, \mathrm{v}$ & $\mathrm{V}, \mathrm{v}$ & $\mathrm{W}, \mathrm{w}$ \\
\hline$\Gamma, \Gamma$ & $\mathrm{H}$ & $\mathrm{G}, \mathrm{g}$ & $\mathrm{H}, \mathrm{h}$ & $\mathrm{H}, \mathrm{h}$ \\
\hline E, e & $\mathrm{E}$ & $\mathrm{E}, \mathrm{e}$ & $\begin{array}{l}\text { Je - na początku wyrazu, } \\
\text { po samogłosce, po apo- } \\
\text { strofie ('), znaku mięk- } \\
\text { kim (b) po } u \text { niezgłosko- } \\
\text { twórczym (y̆) } \\
\text { ie - po spółgłosce (też } \\
\text { Л, л) }\end{array}$ & $\begin{array}{l}\text { Je, je - na początku wy- } \\
\text { razu, po samogłosce, po } \\
\text { apostrofie ('), znaku mięk- } \\
\text { kim (b) } \\
\text { e - po Л, л } \\
\text { ie - po innych spółgło- } \\
\text { skach }\end{array}$ \\
\hline$\ddot{\mathrm{E}}, \ddot{\mathrm{e}}$ & $\mathrm{IO}$ & $\ddot{\mathrm{E}}, \ddot{\mathrm{e}}$ & $\begin{array}{l}\text { Jo - na początku wyrazu, } \\
\text { po samogłosce, po apo- } \\
\text { strofie ('), znaku miękkim } \\
\text { (b) po } u \text { niezgłoskotwór- } \\
\text { czym (y) } \\
\text { io - po spółgłosce (też } \\
\text { Л, л) }\end{array}$ & $\begin{array}{l}\text { Jo, jo - na początku wy- } \\
\text { razu, po samogłosce, po } \\
\text { apostrofie ('), znaku mięk- } \\
\text { kim (b) } \\
\text { o - po Л, л } \\
\text { io - po innych spółgło- } \\
\text { skach }\end{array}$ \\
\hline Ж, ж & $\mathrm{ZH}$ & $\check{Z}, \check{z}$ & $\check{Z}, \check{z}$ & $\dot{\mathrm{Z}}, \dot{\mathrm{z}}$ \\
\hline $\mathrm{I}, \mathrm{i}$ & I & İ, ì & $\mathrm{I}, \mathrm{i}$ & $\mathrm{I}, \mathrm{i}$ \\
\hline$\breve{И}$, й & $\mathrm{I}$ & $J, j$ & $\mathrm{~J}, \mathrm{j}$ & $\mathrm{J}, \mathrm{j}$ \\
\hline Л, л & $\mathrm{L}$ & $\mathrm{L}, \mathrm{l}$ & $\mathrm{L}, \mathrm{l}$ & $\begin{array}{l}\mathrm{L}, 1 \text { - przed e, ë, Я, ю, i, b } \\
\text { Ł, } 1 \text { - przed spółgłoskami, } \\
\text { przed samogłoskami a, o, } \\
\text { y, b oraz na końcu wyrazu }\end{array}$ \\
\hline y̆, y̆ & $\mathrm{U}$ & 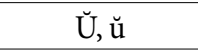 & $\breve{U}, \breve{\mathrm{u}}$ & $\mathrm{U}, \mathrm{u}$ \\
\hline $\mathrm{X}, \mathrm{x}$ & $\mathrm{KH}$ & $\mathrm{H}, \mathrm{h}$ & $\mathrm{Ch}, \mathrm{ch}$ & $\mathrm{Ch}, \mathrm{ch}$ \\
\hline Ц, ц & TS & $\mathrm{C}, \mathrm{c}$ & $\mathrm{C}, \mathrm{c}$ & $\mathrm{C}, \mathrm{c}$ \\
\hline Ч, ч & $\mathrm{CH}$ & $\check{C}, \check{c}$ & $\check{C}, \check{c}$ & $\mathrm{Cz}, \mathrm{cz}$ \\
\hline Ш, ш & $\mathrm{SH}$ & $\check{S}, \check{s}$ & $\check{S}, \check{s}$ & $\mathrm{Sz}, \mathrm{sz}$ \\
\hline ' & Pomija się & ' & Pomija się & Pomija się \\
\hline
\end{tabular}




\begin{tabular}{|c|c|c|c|c|}
\hline $\begin{array}{c}\text { Alfabet } \\
\text { białoruski }\end{array}$ & $\begin{array}{l}\text { Transliteracja } \\
\text { Organizacji } \\
\text { Międzynarodo- } \\
\text { wego Lotnictwa } \\
\text { Cywilnego } \\
\text { (stosowana } \\
\text { w paszportach) }\end{array}$ & $\begin{array}{l}\text { Transliteracja } \\
\text { ISO 9: } 1995 \\
\text { PN-ISO 9:2000 } \\
\text { (dotyczy zapi- } \\
\text { sów bibliogra- } \\
\text { ficznych) }\end{array}$ & $\begin{array}{l}\text { Transliteracja } \\
\text { (oficjalny system biało- } \\
\text { ruski z } 2007 \text { r. zalecony } \\
\text { przez ONZ w } 2012 \text { r., } \\
\text { dotyczy zapisów nazw } \\
\text { geograficznych) }\end{array}$ & Transkrypcja polska \\
\hline $\mathbf{b}$ & Pomija się & , & $\begin{array}{l}\text { Znak miękkości zazna- } \\
\text { czany jest nad literami: Ć, } \\
c ́, \hat{N}, \text { ń, Ś, ś, Ź, ź oraz Ĺ, l }\end{array}$ & $\begin{array}{l}\text { Znak miękkości zazna- } \\
\text { czany jest nad literami: Ć, } \\
\text { ć, Ń, ń, Ś, ś, ́́, ź. Pomijany } \\
\text { jest po Л, л. Ль, ль zapisy- } \\
\text { wane jest jako L, l }\end{array}$ \\
\hline Э, Э & $\mathrm{E}$ & È, è & E, e & $\mathrm{E}, \mathrm{e}$ \\
\hline Ю, ю & IU & $\hat{\mathrm{U}}, \mathrm{u}$ & $\begin{array}{l}\text { Ju, ju - na początku wy- } \\
\text { razu, po samogłosce, po } \\
\text { apostrofie ('), znaku mięk- } \\
\text { kim (b) po } u \text { niezgłosko- } \\
\text { twórczym (y̆) } \\
\text { iu - po spółgłosce (też } \\
Л, \pi)\end{array}$ & $\begin{array}{l}\text { Ju, ju - na początku wy- } \\
\text { razu, po samogłosce, po } \\
\text { apostrofie ('), znaku mięk- } \\
\text { kim (b) } \\
\text { u - po Л, л } \\
\text { iu - po innych spółgło- } \\
\text { skach }\end{array}$ \\
\hline Я, я & & $\hat{A}, \hat{a}$ & $\begin{array}{l}\text { Ja, ja - na początku wy- } \\
\text { razu, po samogłosce, po } \\
\text { apostrofie ('), znaku mięk- } \\
\text { kim (b) po } u \text { niezgłosko- } \\
\text { twórczym (y̆) } \\
\text { ia - po spółgłosce (też } \\
\text { Л, л) }\end{array}$ & $\begin{array}{l}\text { Ja, ja - na początku wy- } \\
\text { razu, po samogłosce, po } \\
\text { apostrofie ('), znaku mięk- } \\
\text { kim (ь) } \\
\text { a - po Л, л } \\
\text { ia - po innych spółgło- } \\
\text { skach }\end{array}$ \\
\hline
\end{tabular}

Na samej Białorusi nie ma jednego sposobu oddawania nazwisk białoruskich literami alfabetu łacińskiego, stąd pytanie, czy w innych krajach taki jeden sposób powinien funkcjonować. Wielość wariantów transliteracji budzi duże kontrowersje wśród samych Białorusinów (por. Лычавко, 2012; Kaleta, 2014, ss. 94-96; Сомін, w druku), zapewne dlatego, że zwykli obywatele nie odróżniają zasad i celów transliteracji od zasad i celów transkrypcji, stąd oczekują jednego, uniwersalnego sposobu transliteracji alfabetu białoruskiego. Brak jednolitości tworzy problemy w polskich urzędach zarówno urzędnikom, jak i zgłaszającym się do nich obcokrajowcom, dlatego właśnie tendencje do ujednolicania transliteracji zyskują coraz większe grono zwolenników i na Białorusi, i w Polsce.

Polskie urzędy stanu cywilnego wydają dokumenty (np. umiejscowione akty urodzenia czy ślubu), w których nazwiska białoruskie pisane są w polskiej transkrypcji, różniącej się znacznie od angielskiej transliteracji stosowanej 
w białoruskich paszportach. Z kolei Urząd ds. Cudoziemców wydaje dokumenty (karty pobytu) $\mathrm{z}$ nazwiskiem $\mathrm{w}$ takiej formie, jaka widnieje $\mathrm{w}$ paszporcie, co prowadzi do sytuacji, że obywatel Białorusi ma w Polsce dwa polskie dokumenty $\mathrm{z}$ różnymi formami nazwiska i do tego jeszcze paszport. Obywatele Białorusi często właśnie paszport uważają za najważniejszy dokument i domagają się, by w każdym dokumencie (i nie tylko dokumencie) polskim widniała forma nazwiska taka jak w paszporcie. Czasami potrzebne jest specjalne zaświadczenie $\mathrm{z}$ ambasady potwierdzające, że obie formy nazwiska lub imienia odnoszą się do tej samej osoby. Zaświadczenie takie należy jeszcze przetłumaczyć na język polski u tłumacza przysięgłego, co dodatkowo pogłębia biurokrację. Niżej podajemy formy imion i nazwisk białoruskich funkcjonujące w dokumentach.

Tabela 7. Przykłady imion i nazwisk białoruskich w dokumentach

\begin{tabular}{|c|c|c|c|}
\hline $\begin{array}{c}\text { Imię / nazwisko po } \\
\text { białorusku }\end{array}$ & $\begin{array}{c}\text { W paszporcie / kar- } \\
\text { cie pobytu w RP }\end{array}$ & $\begin{array}{c}\text { USC w RP (trans- } \\
\text { krypcja polska) }\end{array}$ & $\begin{array}{c}\text { Proponowane ujedno- } \\
\text { licenie na podstawie } \\
\text { systemu białoruskiego } \\
\text { z 2007 r. zaleconego } \\
\text { przez ONZ w 2012 r. } \\
\text { co do nazw geogra- } \\
\text { ficznych }\end{array}$ \\
\hline Варонка & VARONKA & Waronka & Varonka \\
\hline Ефрасіня & EFRASINIA & Jefrasinia & Jefrasinia \\
\hline Кныш & KNYSH & Knysz & Knyš \\
\hline Крысціна & KRYSTSINA & Kryscina & Kryscina \\
\hline Семянькевіч & SEMIANKEVICH & Siemiańkiewicz & Siemiańkievič \\
\hline Хаўстовіч & КHAUSTOVICH & Chaustowicz & Chaŭstovič \\
\hline
\end{tabular}

W Polsce na karcie pobytu nazwisko białoruskie ma taką formę, jak w paszporcie, ale już w dokumentach USC będzie widnieć w transkrypcji polskiej. Oba dokumenty wydawane są przez polskie urzędy z polskim godłem. Trudno rozstrzygnąć, czy urzędnik musi rozumieć, że Efrasinia z paszportu i karty pobytu jest Jefrasinią z umiejscowionego w Polsce aktu ślubu, ale praktyka pokazuje, że nie musi, zwłaszcza że na pierwszy rzut oka imię zaczyna się na inną literę. W ostatniej kolumnie tabeli utworzono imiona i nazwiska na podstawie międzynarodowej rekomendacji ONZ co do zapisu nazw geograficznych. Na Białorusi mówi się o oczekiwaniach społecznych, dotyczących ujednolicenia do tego wariantu wszystkich form białoruskich - więc także nazwisk i imion w paszportach - na wzór paszportów polskich czy litewskich, gdzie zachowane są w górnej części 
dokumentu paszportowego litery narodowe. Jeżeli imię RADOSŁAW ma na dole formę RADOSLAW (według transliteracji ICAO), to $-\mathrm{z}$ białoruskiego punktu widzenia - równie dobrze można by pisać na górze CHAǓSTOVIČ i na dole CHAUSTOVIC (według transliteracji ICAO), czyli bez znaków diakrytycznych. Niektórzy badacze białoruscy twierdzą, że byłoby dobrze, gdyby białoruskie zasady dotyczące transliteracji nazw geograficznych, zaakceptowane przez ONZ, były stosowane w każdym przypadku, także wobec imion i nazwisk, oddając tym samym białoruskie cechy językowe. Gdyby taka unifikacja odbyła się na Białorusi, to miałaby swoje konsekwencje też dla zwykłych obywateli w Polsce, gdyż łatwiej jest poprawnie odczytać z dokumentu nazwisko CHAŬSTOVIČ niż KHAUSTOVICH. Ujednolicanie transliteracji jest procesem złożonym, nad którym powinno pochylić się grono ekspertów, składające się z językoznawców i urzędników. Poszczególni badacze mogą jednak proponować pewne rozwiązania do dyskusji, zwłaszcza że trudno jest znaleźć jedno satysfakcjonujące wyjście. Do rozważenia poddajemy także jeden z pomysłów. W polskich dokumentach mogłyby funkcjonować dwa warianty transliteracji w zależności od tego, czy obcokrajowiec jest już obywatelem RP, czy jeszcze nie. Jeśli Białorusin nie jest jeszcze obywatelem RP, to we wszystkich dokumentach (z USC i w karcie pobytu) ma formę nazwiska taką jak w paszporcie, ewentualnie z dopiskiem o obywatelstwie białoruskim (np. KHAUSTOVICH lub CHAǓSTOVIČ, obywatel Białorusi), natomiast z chwilą przyjęcia obywatelstwa polskiego następowałaby zmiana formy nazwiska na tę zgodną z polską transkrypcją, czyli CHAUSTOWICZ, z jednoczesnym wydaniem dokumentu, że KHAUSTOVICH lub CHAǓSTOVIČ i CHAUSTOWICZ są tą samą osobą. W ten sposób zachowane zostałyby białoruskie i polskie konwencje, a forma nazwiska wskazywałaby, czy dana osoba jest obywatelem RP, czy nie. W przypadku nadania obywatelstwa polskiego do rozważenia byłaby jeszcze jedna zasada dotycząca imion. Osoba przyjmująca obywatelstwo polskie mogłaby otrzymywać polski odpowiednik (jeśli istnieje) swojego imienia. Białoruski Мiкалаŭ w polskiej transkrypcji ma formę Mikałaj (a nie Mikołaj). Jeśli jest to już obywatel RP, to forma ta w polskich dokumentach może wyglądać na literówkę, gdyż trudno znaleźć Polaka o imieniu Mikałaj. Forma taka zdradza też pochodzenie, czego nie musi sobie życzyć osoba nosząca to imię, choć z drugiej strony właśnie może chcieć, by forma imienia nawiązywała do białoruskiego oryginału. W Polsce potrzebna jest zatem dyskusja dotyczą ujednolicenia transliteracji alfabetu języka białoruskiego w polskich dokumentach. Zaprezentowane w niniejszym artykule rozwiązania jako jeden z głosów - mogą służyć wypracowaniu satysfakcjonujących rozwiązań. 


\section{Bibliografia}

Bańko, M. (Red.). (2006). Polszczyzna na co dzień. Warszawa: Wydawnictwo Naukowe PWN. International Organization for Standardization. (1995). ISO 9 1995: Information and documentation - Transliteration of Cyrillic characters into Latin characters - Slavic and non-Slavic languages.

International Organization for Standardization. (2000). PN-ISO 9:2000: Informacja i dokumentacja. Transliteracja znaków cyrylickich na znaki łacińskie - Języki słowiańskie i niesłowiańskie.

Kaleta, R. (2014). Białorusko-polska homonimia międzyjęzykowa. Warszawa: Instytut Slawistyki Polskiej Akademii Nauk.

Lubaś, W. (2009). Komparacja współczesnych języków słowiańskich: Polityka językowa. Opole: Wydawnictwo Uniwersytetu Opolskiego.

Lukašanec, A., Prigodzič, M., \& Sjameška, L. (Red.). (1998). Najnowsze dzieje języków słowiańskich: Беларуская мова. Opole: Uniwersytet Opolski.

Łodziński, S. (2005). Niebanalna dwujęzyczność: Polska tożsamość narodowa a granice integracji mniejszości narodowych. W: W. J. Burszta, K. Jaskułowski, \& J. Nowak (Red.), Naród - Tożsamość - Kultura: Między koniecznościq a wyborem (ss. 177-197). Warszawa: Instytut Slawistyki Polskiej Akademii Nauk.

Polański, E. (Red.). (2013). Wielki słownik ortograficzny PWN z zasadami pisowni i interpunkcji. Warszawa: Wydawnictwo Naukowe PWN.

Report on the current status of United Nations romanization systems for geographical names. (b.d.). Pobrano 21 grudnia 2015, z http://www.eki.ee/wgrs/

Romanowski, A. (2000). Dylematy językowe Białorusinów w przeszłości i dziś. W: M. Bobrownicka (Red.), Język a tożsamość narodowa: Slavica (ss. 123-133). Kraków: Towarzystwo Autorów i Wydawców Prac Naukowych „Universitas”.

Rozporządzenie Ministra Spraw Wewnętrznych i Administracji z dnia 30 maja 2005 r. w sprawie sposobu transliteracji imion i nazwisk osób należących do mniejszości narodowych i etnicznych zapisanych w alfabecie innym niż alfabet łaciński (Dz. U. Nr 102, poz. 855). (2005). Pobrano 21 grudnia 2015, z http://www.mniejszosci.narodowe.mac.gov.pl/mne /prawo/zapisy-z-konstytucji-r/6448, Rozporzadzenie-Ministra-Spraw-Wewnetrznych-iAdministracji-w-sprawie-sposobu-tra.html

Smułkowa, E. (2002). Białoruś i pogranicza: Studia o języku i społeczeństwie. Warszawa: Wydawnictwa Uniwersytetu Warszawskiego.

Баршчэусская, Н. (2004). Беларуская эміграцыя - абарониа беларускае мовы. Варшава: Катэдра Беларускай Філялёгіi, Факультэт Прыкладной Лінгвістыкі і Ўсходнеславянскіх Філялёгіяў, Варшаўскі Ўніверсітэт.

Инструкция по транслитерации географических названий Республики Беларусь буквами латинского алфавита. (b.d.). Pobrano 21 grudnia 2015, z http://www.webcitation .org/6XUwabw3U

Кошчанка, У. А. (2015). Ад „геаграфічнай” лацінкі да нацыянальнай сістэмы раманізацыі беларускай мовы. W: A. М. Анісім (Red.), Зборнік матэрыялаў Міжнароднай навукова- 
практычнай канферэниьы «Моўныя правы і іх абарона», 28 сакавіка 2015 г. (Т. 1, ss. 171-178). Мінск.

Лукашанец, А. А. (2014). Беларуская мова у ХХІ стагоддзі: Развіциё сістэмы і праблемы функцьяннавання. Мінск: Беларуская навука.

Лычавко, А. (2012). Какой транслит правильный? Pobrano 21 grudnia 2015, z http://news .tut.by/society/309486.html

Плотнікаў, Б. (2000). Беларуская мова ў сістэме славянскіх моў. Роднае слова, (6), 36-40. Саўка, 3. (2011). Беларускае ў іншамоўным: Шляхі стандарызацыі. Acta Albaruthenica, 11, 231-238.

Сомін, А. (w druku). Праблема транслітарацыі ўласных імёнаў і наіўная моўная рэблексія (укантэксие руска-беларускага білінгвізму).

\section{Bibliography (Transliteration)}

Bańko, M. (Ed.). (2006). Polszczyzna na co dzień. Warszawa: Wydawnictwo Naukowe PWN.

Barshchėŭskaia, N. (2004). Belaruskaia émihratsyia - abarontsa rodnae movy. Varshava: Katèdra Belaruskaı̆ Filialiohii, Fakultèt Prykladnoŭ Linhvistyki i Ǔskhodneslavianskikh Filialiohiiaŭ, Varshaŭski Ŭniversytèt.

Instruktsiia po transliteratsii geograficheskikh nazvaniĭ Respubliki Belarus' bukvami latinskogo alfavita. (n.d.). Retrieved 21 December 2015, from http://www.webcitation.org/6XUwabw3U

International Organization for Standardization. (1995). ISO 9 1995: Information and documentation Transliteration of Cyrillic characters into Latin characters - Slavic and non-Slavic languages.

International Organization for Standardization. (2000). PN-ISO 9:2000: Informacja i dokumentacja. Transliteracja znaków cyrylickich na znaki łacińskie - Języki słowiańskie i niesłowiańskie.

Kaleta, R. (2014). Białorusko-polska homonimia międzyjęzykowa. Warszawa: Instytut Slawistyki Polskiej Akademii Nauk.

Koshchanka, U. A. (2015). Ad «heahrafichnằ latsinki da natsyianal'naĭ sistėmy ramanizatsyi belaruskaĭ movy. In A. M. Anisim (Ed.), Zbornik materryialaŭ Mizhnarodna navukovapraktychnă kanferèntsyi «Moŭnyia pravy i ikh abarona», 28 sakavika 2015 h. (Vol. 1, pp. 171-178). Minsk.

Lubaś, W. (2009). Komparacja współczesnych języków słowiańskich: Polityka językowa. Opole: Wydawnictwo Uniwersytetu Opolskiego.

Lukašanec, A., Prigodzič, M., \& Sjameška, L. (Eds.). (1998). Najnowsze dzieje języków słowiańskich: Belaruskaia mova. Opole: Uniwersytet Opolski.

Lukashanets, A. A. (2014). Belaruskaia mova ŭ XXI stahoddzi: Razvitstsio sistemy i prablemy funktsyianavannia. Minsk: Belaruskaia navuka.

Lychavko, A. (2012). Kakoĭ translit pravil'nyı̌? Retrieved 21 December 2015, from http://news .tut.by/society/309486.html

Łodziński, S. (2005). Niebanalna dwujęzyczność: Polska tożsamość narodowa a granice integracji mniejszości narodowych. In W. J. Burszta, K. Jaskułowski, \& J. Nowak (Eds.), 
Naród - Tożsamość - Kultura: Między koniecznościqa a wyborem (pp. 177-197). Warszawa: Instytut Slawistyki Polskiej Akademii Nauk.

Plotnikaŭ, B. (2000). Belaruskaia mova ŭ sistėme slavianskikh moŭ. Rodnae slova, (6), 36-40. Polański, E. (Ed.). (2013). Wielki słownik ortograficzny PWN z zasadami pisowni i interpunkcji. Warszawa: Wydawnictwo Naukowe PWN.

Report on the current status of United Nations romanization systems for geographical names. (n.d.). Retrieved 21 December 2015, from http://www.eki.ee/wgrs/

Romanowski, A. (2000). Dylematy językowe Białorusinów w przeszłości i dziś. In M. Bobrownicka (Ed.), Język a tożsamość narodowa: Slavica (pp. 123-133). Kraków: Towarzystwo Autorów i Wydawców Prac Naukowych "Universitas."

Rozporządzenie Ministra Spraw Wewnętrznych i Administracji z dnia 30 maja 2005 r. w sprawie sposobu transliteracji imion i nazwisk osób należących do mniejszości narodowych i etnicznych zapisanych w alfabecie innym niż alfabet łaciński (Dz. U. Nr 102, poz. 855). (2005). Retrieved 21 December 2015, from http://www.mniejszosci.narodowe.mac.gov.pl /mne/prawo/zapisy-z-konstytucji-r/6448,Rozporzadzenie-Ministra-Spraw-Wewnetrznychi-Administracji-w-sprawie-sposobu-tra.html

Saŭka, Z. (2011). Belaruskae ŭ inshamoŭnym: Shliakhi standaryzatsyi. Acta Albaruthenica, 11, 231-238.

Smułkowa, E. (2002). Białoruś i pogranicza: Studia o języku i społeczeństwie. Warszawa: Wydawnictwa Uniwersytetu Warszawskiego.

Somin, A. (in press). Prablema translitaratsyi ŭlasnykh imionaŭ i naiŭnaia moŭnaia réfleksiia (u kantèkstse ruska-belaruskaha bilinhvizmu).

\section{Towards standards in transliteration of Belarusian names and surnames in Poland}

\section{Summary}

The article presents many transliteration variants of Belarusian names and surnames in Poland. It discusses the most common variants of the Belarusian alphabet transliteration, both international and Belarusian, as well as Polish transcription. The multiplicity of variants raises technical problems in the documents (passports, residence permits, acts of birth etc.). The article is a voice in the discussion on the development of a unified system of transliteration of Belarusian alphabet for the needs of the documents recognized in Poland. 


\section{O potrzebie ujednolicenia sposobów transliteracji imion i nazwisk białoruskich w Polsce}

\section{Streszczenie}

Artykuł prezentuje wielość wariantów transliteracji imion i nazwisk białoruskich w Polsce. Przedstawiono najpopularniejsze warianty transliteracji alfabetu białoruskiego - zarówno międzynarodowe, jak i białoruskie - oraz transkrypcję polską. Wielość wariantów rodzi problemy natury technicznej w dokumentach (paszporty, karty pobytu, akty urodzin itd.). Artykuł jest głosem w dyskusji na temat opracowania ujednoliconego systemu transliteracji alfabetu białoruskiego na potrzeby dokumentów uznawanych w Polsce.

Keywords: Belarusian language; Polish language; transliteration; transcription; names

Słowa kluczowe: język białoruski; język polski; transliteracja; transkrypcja; imiona

\footnotetext{
Radosław Kaleta, Department of Belorussian Studies, Faculty of Applied Linguistics, University of Warsaw Correspondence: rkaleta@uw.edu.pl

The preparation of the article has been financed within the statutory activities of the Department of Belorussian Studies, University of Warsaw.

Competing interests: The author has declared he has no competing interests.
} 